\title{
STUDY TO SHOW THE EFFECT OF INTRAHEPATIC CHOLESTASIS OF PREGNANCY ON PERINATAL OUTCOME IN UNCOMPLICATED PREGNANCY
}

\author{
Shalini Singla1, Preety Aggarwal2, Ashwani Mittal ${ }^{3}$ \\ ${ }^{1}$ Assistant Professor, Department of Obstetrics and Gynaecology, Maharaja Agrasen Medical College, Agroha. \\ ${ }^{2}$ Senior Resident, Department of Obstetrics and Gynaecology, Maharaja Agrasen Medical College, Agroha. \\ ${ }^{3}$ Consultant, Department of Paediatrics, Sarvodaya Multispeciality Hospital, Hisar.
}

\begin{tabular}{l}
\hline ABSTRACT \\
\hline OBJECTIVE \\
To study the effect of Intrahepatic Cholestasis of Pregnancy on perinatal outcome with medical management and timely \\
intervention in the form of induction of labour or Caesarean Section and its comparison with Control group.
\end{tabular}

\section{METHODS}

This prospective study was conducted on pregnant women attending the Antenatal Clinic of Outpatient and Indoor Department of Obstetrics and Gynaecology of Maharaja Agrasen Hospital, Punjabi Bagh, New Delhi from August 2009 till July $2011 ; 50$ Pregnant patients who developed pruritus during $2^{\text {nd }}$ and $3^{\text {rd }}$ trimester of pregnancy with or without jaundice and were having elevated total bile acids $>10 \mathrm{umol} / \mathrm{L}$ with or without deranged liver function tests were taken as cases and 50 Pregnant patients without ICP were taken as control.

\section{RESULTS}

In our study, intrahepatic cholestasis was associated with:

1. Increased incidence of intrapartum thick meconium staining of amniotic fluid (30\% in Cases and $10 \%$ in Control).

2. The rate of induced delivery in the form of emergency caesarean section or induced labour was also high (34\% in Cases and $14 \%$ in Control).

3. Increased incidence of low birth weight ( $<2500 \mathrm{gms}$ ) and low mean birth weight, i.e. $21.5 \%$ in Cases and $6 \%$ in Control group with active intervention at 37 weeks.

\section{CONCLUSION}

From the above study we concluded that ICP is associated with increased rate of preterm delivery, caesarean sections, low birth weight babies and still birth.

\section{KEYWORDS}

ICP, Meconium Staining, Preterm.

HOW TO CITE THIS ARTICLE: Singla S, Aggarwal P, Mittal A. Study to show the effect of intrahepatic cholestasis of pregnancy on perinatal outcome in uncomplicated pregnancy. J. Evolution Med. Dent. Sci. 2016;5(69):4964-4966, D0I: $10.14260 /$ jemds/2016/1127

\section{INTRODUCTION}

Pregnancy is a nature's precious gift, which has to be nurtured during its entire nine months of duration to achieve good maternal and foetal outcome. There are several complications, which may impair a favourable pregnancy outcome. During this physiological event some women develop liver disorders during their second or third trimester of pregnancy that may endanger the mother, her baby or both. Approximately, 3-5\% of pregnant women have deranged liver function tests with or without jaundice.

Causes of Jaundice or Deranged Liver Function Tests Specific to Pregnancy Include

- Pre-eclampsia associated with HELLP syndrome (Haemolysis, Elevated Liver Enzymes and Low Platelet Count).

Financial or Other, Competing Interest: None.

Submission 06-01-2016, Peer Review 14-04-2016,

Acceptance 18-04-2016, Published 26-08-2016.

Corresponding Author:

Dr. Shalini Singla,

Assistant Professor

Department of Obstetrics and Gynaecology,

MAMC, Agroha,

E-mail: drvishal1981@gmail.com

DOI: $10.14260 /$ jemds/2016/1127
- Acute fatty liver of pregnancy.

- Hyperemesis gravidarum.

- Intrahepatic Cholestasis of Pregnancy (ICP), also known as cholestasis of pregnancy, recurrent jaundice of pregnancy or pruritus gravidarum.

Intrahepatic Cholestasis of Pregnancy is an uncommon cholestatic liver disorder characterized by pruritus with onset in the $2^{\text {nd }}$ or $3^{\text {rd }}$ trimester of pregnancy with or without increase in serum bilirubin, serum aminotransferases, alkaline phosphatases and elevated total bile acid level more than 10 micromoles/litre..$^{1,2}$ The diagnosis is based on history, clinical examination and laboratory findings, but in general ICP is a diagnosis of exclusion. Once the diagnosis of ICP is made, treatment should be initiated immediately.

In contrast to favourable prognosis for the mother, ICP poses significant risk for the foetus. The rate of malformation and abortion is not increased in ICP. There is increased risk of spontaneous preterm labour in ICP.3,4 The incidence of meconium staining of amniotic fluid in normal term pregnancy is approximately $15 \%$ and is considered to be a sign of foetal distress. ${ }^{5}$ In ICP incidence of meconium staining of amniotic fluid has been reported to be $16-58 \%$. ICP have reported a perinatal mortality of $10-15 \%$. 
This has been reduced to $3.5 \%$ or less in more recent studies employing policies of active management. Many pharmacological agents have been used in the treatment of Intrahepatic Cholestasis of Pregnancy (ICP). ${ }^{6}$ These include phenobarbital, hydroxyzine, glutathione precursor such as Sadenosyl methionine (SAME), cholestyramine and dexamethasone. UDCA is the drug of choice for the treatment of ICP.7,8

UDCA at a daily dose ranging from $600-2000 \mathrm{mg}$ was effective at reducing pruritus, decreasing the total serum bile acid levels, ALT values and bilirubin levels. The purpose of this work is to study the effect of intrahepatic cholestasis of pregnancy on perinatal outcome in uncomplicated pregnancy.

\section{MATERIAL AND METHODS}

This is a prospective clinical study conducted on 100 patients in Maharaja Agrasen Hospital, Punjabi Bagh, Delhi who attended outpatient and indoor Department of Obstetrics and Gynaecology.

\section{Inclusion Criteria}

1. 50 Pregnant patients who developed pruritus during $2^{\text {nd }}$ and $3^{\text {rd }}$ trimester of pregnancy with or without jaundice and were having elevated total bile acids $>10 \mathrm{umol} / \mathrm{L}$ with or without deranged liver function tests were taken as cases.

2. 50 Pregnant patients without ICP were taken as control.

\section{Exclusion Criteria}

1. Signs of dermatological disease on clinical examination.

2. Itching due to allergic disorders.

3. Presence of other active liver disease.

4. HELLP syndrome, acute fatty liver of pregnancy.

Detailed medical history (Especially regarding onset of pruritus, site of pruritus, diurnal variation and development of jaundice), obstetrics history with clinical examination was recorded at every visit. The maternal data collected included maternal age, gestational age at the time of delivery, parity, history of ICP in previous pregnancies, history of biliary or any liver disease and mode of delivery. The biochemical investigations done were serum total bile acids, serum bilirubin, serum aminotransferases, serum alkaline phosphatases. Serum laboratory tests were done at the onset of signs and symptoms of ICP.

Patients were given palliation initially with topical emollients, antihistaminics and Ursodeoxycholic Acid (UDCA) during antenatal and postnatal period up to 2 weeks. Patients were monitored after 32 weeks weekly by NST. Pregnancy complicated by ICP were managed actively at 37 weeks of gestation or when the patient presented first after 37 weeks or earlier if required in patients developing other obstetrics complication. Incidence of meconium stained liquor at the time of delivery, preterm delivery i.e. $<37$ weeks, APGAR score at 5 mins. $<7$, low birth weight i.e. $<2500$ gms, neonatal admission to nursery and perinatal death were noted. The incidence of these perinatal outcome parameters in Control group were also noted.

In our study, levels were measured by enzymatic spectrophotometric method. In this method, the enzyme 3- $\alpha-$ hydroxysteroid dehydrogenase converts bile acids to 3 ketosteroids and Thio-NADH.
In the presence of excess NADH, enzyme cycling occurs efficiently and rate of formation of Thio-NADH is determined by measuring specific change of absorbance at $405 \mathrm{~nm}$.

In our study serum bile acids were measured by kit available from Diazyme Laboratories in name of Total Bile Acids Assay Kit. Statistical analysis was conducted with the Statistical Package for the Social Sciences (SPSS) version 12.0.

Means, standard deviations and ranges were calculated for descriptive purposes. A P value $<0.05$ was considered significant.

\section{RESULTS}

The mean age of patients in Study group was $28.04 \pm 3.68$ and in Control group was $27.64 \pm 3.70$. The difference in the age of two groups was statistically not significant. In Study group, 34 (68\%) were primigravida and in Control group 33 (66\%). The mean gestational age in ICP group was $30 \pm 4.7$ weeks. The mean age of Control group was $31.2 \pm 3$.3 weeks. Only one twin pregnancy in Study group, but none in control one. In Study group $22 \%$ have non-reassuring CTG, while only $10 \%$ in Control group. The two-sided $\mathrm{P}$ value is 0.1651 , considered not significant; $28 \%$ and $10 \%$ preterm deliveries in Study and Control group respectively.

Meconium staining was present in $30 \%$ and in $10 \%$ in Study and Control group. Induction was done in $34 \%$ cases in Study group and $14 \%$ cases in Control group. Caesarean section was done in $40 \%$ and $20 \%$ cases in study and Control group respectively. Most common indication for caesarean section was non-reassuring CTG during intrapartum period. Low birth weight babies were $21.5 \%$ and $6 \%$ in Study and Control group. Apgar score $<7$ in $19.26 \%$ cases and $8 \%$ cases in Study and Control group respectively; $38 \%$ of neonates in Study group and $24 \%$ in Control group got admitted to NICU. There was 2 perinatal deaths in Study group as compared to nil in Control group.

\begin{tabular}{|c|c|c|}
\hline & $\begin{array}{c}\text { Spontaneous } \\
\text { Preterm } \\
\text { Delivery }\end{array}$ & $\begin{array}{c}\text { Induced } \\
\text { Preterm } \\
\text { Delivery }\end{array}$ \\
\hline Study Group & 10 & 04 \\
\hline Control Group & 03 & 02 \\
\hline $\begin{array}{c}\text { Table 1: Comparison of Spontaneous versus Induced } \\
\text { Preterm Delivery in Study and Control Group }\end{array}$ \\
\hline
\end{tabular}

\begin{tabular}{|c|c|c|c|}
\hline & $\begin{array}{c}\text { Meconium } \\
\text { Stained } \\
\text { Amniotic } \\
\text { Fluid }\end{array}$ & $\begin{array}{c}\text { Normal } \\
\text { Amniotic } \\
\text { Fluid }\end{array}$ & \\
\hline Study Group & 15 & 35 & $15 / 50(30 \%)$ \\
\hline Control Group & 05 & 45 & $05 / 50(10 \%)$ \\
\hline
\end{tabular}

Table 2: Comparison of Meconium Stained Amniotic Fluid in Study and Control Group

\begin{tabular}{|c|c|c|c|}
\hline & $\begin{array}{c}\text { Induced } \\
\text { Labour }\end{array}$ & $\begin{array}{c}\text { Spontaneous } \\
\text { Labour }\end{array}$ \\
\hline Study Group & 17 & 33 & $17 / 50(34 \%)$ \\
\hline Control Group & 07 & 43 & $07 / 50(14 \%)$ \\
\hline \multicolumn{3}{|c|}{ Table 3: Comparison of Induced Labour } \\
in Study and Control Group \\
\hline
\end{tabular}

\begin{tabular}{|c|c|c|c|}
\hline & $\begin{array}{c}\text { Caesarean } \\
\text { Section }\end{array}$ & $\begin{array}{c}\text { Normal } \\
\text { Delivery }\end{array}$ & \\
\hline Study Group & 20 & 30 & $20 / 50(40 \%)$ \\
\hline Control Group & 10 & 40 & $10 / 50(20 \%)$ \\
\hline \multicolumn{3}{|r|}{ Table 4: Comparison of Caesarean Section } \\
Done in Study and Control Group
\end{tabular}




\begin{tabular}{|c|c|c|c|}
\hline & $\begin{array}{c}\text { Birth } \\
\text { Weight } \\
<2.500 ~ k g\end{array}$ & $\begin{array}{c}\text { Birth } \\
\text { Weight } \\
>2.500 ~ k g\end{array}$ & \\
\hline $\begin{array}{c}\text { Study } \\
\text { Group }\end{array}$ & 11 & 40 & $11 / 51(21.5 \%)$ \\
\hline $\begin{array}{c}\text { Control } \\
\text { Group }\end{array}$ & 03 & 47 & $03 / 50(06 \%)$ \\
\hline \multicolumn{3}{|c|}{$\begin{array}{c}\text { Table 5: Comparison of Low Birth Weight } \\
\text { (<2.500 } \mathbf{~ k g ) ~ i n ~ S t u d y ~ a n d ~ C o n t r o l ~ G r o u p ~}\end{array}$} \\
\hline
\end{tabular}

\begin{tabular}{|c|c|c|c|}
\hline & $\begin{array}{c}\text { Apgar } \\
\text { Score < 7 }\end{array}$ & $\begin{array}{c}\text { Apgar } \\
\text { Score > or=7 }\end{array}$ \\
\hline $\begin{array}{c}\text { Study } \\
\text { Group }\end{array}$ & 11 & 40 & $\begin{array}{c}11 / 51 \\
(19.26 \%)\end{array}$ \\
\hline $\begin{array}{c}\text { Control } \\
\text { Group }\end{array}$ & 04 & 46 & $\begin{array}{c}04 / 50 \\
(08 \%)\end{array}$ \\
\hline \multicolumn{3}{|c|}{$\begin{array}{c}\text { Table 6: Comparison of Apgar Score } \\
\text { at 5 mins. in Study and Control Group }\end{array}$} \\
\hline
\end{tabular}

\begin{tabular}{|c|c|c|c|}
\hline & $\begin{array}{c}\text { Neonate } \\
\text { Admitted } \\
\text { to } \\
\text { Nursery }\end{array}$ & $\begin{array}{c}\text { Neonate } \\
\text { Discharged }\end{array}$ & \\
\hline Study Group & 20 & 31 & $20 / 51(38 \%)$ \\
\hline Control Group & 12 & 38 & $12 / 50(24 \%)$ \\
\hline \multicolumn{3}{|c|}{ Table 7: Comparison of Neonate Admitted } \\
to Nursery in Study and Control Group \\
\hline
\end{tabular}

\begin{tabular}{|c|c|c|c|}
\hline & $\begin{array}{c}\text { Perinatal } \\
\text { Death }\end{array}$ & $\begin{array}{c}\text { Neonate } \\
\text { Discharged }\end{array}$ & \\
\hline Study Group & 02 & 49 & $02 / 51(04 \%)$ \\
\hline Control Group & 00 & 50 & \\
\hline \multicolumn{2}{|r|}{ Table 8: Comparison of Perinatal Death } \\
in Study and Control Group
\end{tabular}

\section{DISCUSSION}

ICP is considered to be a pathology exclusive of gestation associated with adverse perinatal outcome. ${ }^{9}$ The period of gestation of presentation of ICP is mostly during $3^{\text {rd }}$ trimester of pregnancy in $80 \%$ of patients, which is comparable with mean period of gestation in previous studies done by Anna $P$ et al and Bacq Y et al.

Most common presenting symptom was itching. Clinical jaundice was rare as presenting symptoms in our study, which was comparable with studies by Palma J et al and Bacq Y et al. In our study, mean level of ALT and number of patients with raised ALT are lower than previous study.

ICP carries a risk of spontaneous preterm delivery. ${ }^{10}$ In our study, $20 \%(10 / 50)$ had spontaneous preterm delivery which is three-fold as compared to Control group 06\% (03/50) (As shown in Table 1).

In our study, $30 \%$ of patients in Study group had intrapartum meconium staining of amniotic fluid as compared to $10 \%$ in Control group, which is statistically significant (Table 2).

We in our study also found a statistically significant difference in the ratio of induced to spontaneous labour in Study group as compared to Control group (Table 3).

In our study, the incidence of caesarean section is $40 \%$ in Study group as compared to $20 \%$ in Control group and found this difference to be statistically significant (Table 4). Kenyon
AP et al and Ray Alokananda et al found an incidence of 36\% and $31.2 \%$ respectively for caesarean section.

In our study, the incidence of low birth weight $\quad<2500$ gms) is $20 \%$ in Study group as compared to $6 \%$ in Control group (Table 5). The mean birth weight in Study group is 2.720 \pm .468 gms and Control group is $2.914 \pm .361$ gms and the difference between the two is statistically significant ( $P$ value .0221). Heinonen $S$ et al and Reid $R$ et al found lower mean birth weight in ICP group.

Foetal distress is indicated by parameter like low Apgar score ( $<7$ at 5 mins.) and neonatal admission to nursery after birth. In our study, we also found difference in the incidence of Apgar score $<7$ at 5 mins. in ICP group (19.26\%) as compared to non-ICP group (8\%), but this difference was not statistically significant (Table 6). All the 11 neonates with Apgar score $<7$ were having thick intrapartum meconium stained liquor and were kept in nursery (Table 7).

There was 2 perinatal deaths in Study group as compared to nil in Control group. Both foetuses died in ICU due to a possible lethal idiopathic respiratory distress syndrome with prematurity (Table 8).

\section{CONCLUSION}

From the above study we concluded that ICP is associated with increased rate of preterm delivery, both spontaneous and induced, increased incidence of meconium staining, caesarean sections, low birth weight babies and still birth.

\section{REFERENCES}

1. Lammert F, Marschall HU, Glantz A, et al. Intrahepatic cholestasis of pregnancy: molecular pathogenesis, diagnosis and management. J Hepatol 2000;33(6): 1012-21.

2. Beuers U, Pusl T. Intrahepatic cholestasis of pregnancy-a heterogeneous group of pregnancy-related disorders? Hepatology 2006;43(4):647-9.

3. Lee RH, Kwok KM, Ingles S, et al. Pregnancy outcomes during an era of aggressive management for intrahepatic cholestasis of pregnancy. Am J Perinatol 2008;25(6): 341-5.

4. Germain AM, Kato S, Carvajal JA, et al. Bile acids increase response and expression of human myometrial oxytocin receptor. Am J Obstet Gynecol 2003;189(2):577-82.

5. Oztekin D, Aydal I, Oztekin 0, et al. Predicting fetal asphyxia in intrahepatic cholestasis of pregnancy. Arch Gynecol Obstet 2009;280(6):975-9.

6. Kenyon AP, Piercy CN, Girling J, et al. Obstetric cholestasis, outcome with active management: a series of 70 cases. BJOG 2002;109(3):282-8.

7. Glantz A, Marschall HU, Lammert F, et al. Intrahepatic cholestasis of pregnancy: a randomized controlled trial comparing dexamethasone and ursodeoxycholic acid. Hepatology 2005;42(6):1399-405.

8. Alokananda R, Rashne TJ, Roshan B, et al. Cholestasis of pregnancy. J Obstet Gynecol India 2005;55(3):247-50.

9. Saleh MM, Abdo KR. Consensus on the management of obstetric cholestasis: national UK survey. BJOG 2007;114(1):99-103.

10. Lee RH, Incerpi MH, Miller DA, et al. Sudden fetal death in intrahepatic cholestasis of pregnancy. Obstet Gynecol 2009;113(2 Pt 2):528-31. 